\title{
Control of the vegetative growth of 'Shinseiki' pear trees by prohexadione calcium and root pruning
}

\author{
Bruno Carra(1), José Carlos Fachinello(2), Everton Sozo de Abreu(1), Mateus da Silveira Pasa(3), \\ Daniel Spagnol(1), Marcos Antônio Giovanaz ${ }^{(1)}$ and Carina Pereira da Silva ${ }^{(4)}$
}

\begin{abstract}
(1) Universidade Federal de Pelotas, Faculdade de Agronomia Eliseu Maciel, Departamento de Fitotecnia, Campus Universitário, s/no, CEP 96010-900 Capão do Leão, RS, Brazil. E-mail: brunocarra@hotmail.com, sozodeabreu@hotmail.com, spagnol.agro@hotmail.com, giovanazmarcos@gmail.com ${ }^{(2)}$ In memoriam. ${ }^{(3)}$ Empresa de Pesquisa Agropecuária e Extensão Rural de Santa Catarina, Estação Experimental de São Joaquim, Rua João Araújo Lima, no 102, Jardim Caiçara, CEP 88600-000 São Joaquim, SC, Brazil. E-mail: mateuspasa@epagri.sc.gov.br ${ }^{(4)}$ Rua José de Souza Borges, no 102, CEP $88600-000$ São Joaquim, SC, Brazil. E-mail: carpers.rs@gmail.com
\end{abstract}

Abstract - The objective of this work was to evaluate the effect of prohexadione calcium (P-Ca) and root pruning (RP) on the control of the vegetative growth and on fruit production and quality of 'Shinseiki' pear trees, under the climatic conditions of Southern Brazil. The experiment was conducted during the 2013/2014 and 2014/2015 crop seasons, in a 15-year-old orchard of 'Shinseiki' pear trees, trained to a central-leader system, with a $2 \times 5 \mathrm{~m}$ spacing between plants, grafted onto Pyrus calleryana rootstock. The experiment was carried out in a randomized complete block design, with six treatments and four replicate. The treatments consisted of the control (without P-Ca application or RP), two P-Ca rates (300 and $\left.600 \mathrm{mg} \mathrm{L}^{-1}\right)$, two root pruning intensities (performed on one or on both sides of the tree), and root pruning on one side $+300 \mathrm{mg} \mathrm{L}^{-1}$ $\mathrm{P}-\mathrm{Ca}$. P-Ca reduced vegetative growth more effectively than RP, in both crop seasons, and the combination of both techniques did not result in additional control of the vegetative growth, compared with P-Ca alone. Vegetative growth was not affected by increasing the rates of P-Ca. The highest P-Ca dose negativelly affected fruit yield. Regarding fruit quality, RP increases the total soluble solids content at harvest.

Index terms: Pyrus pyrifolia, fruit quality, growth regulators, high-density orchard, vegetative vigor, yield components.

\section{Controle do crescimento vegetativo de pereiras 'Shinseiki' por prohexadiona de cálcio e poda de raiz}

\begin{abstract}
Resumo - O objetivo deste trabalho foi avaliar o efeito da prohexadiona de cálcio (P-Ca) e da poda de raiz (PR) no controle do crescimento vegetativo e na produção e na qualidade dos frutos de pereiras 'Shinseiki', sob condições climáticas do Sul do Brasil. O experimento foi realizado durante as safras de 2013/2014 e 2014/2015, em pomar de pereiras 'Shinseiki' com 15 anos de idade, conduzido em líder central, com espaçamento de $2 \times 5 \mathrm{~m}$ entre plantas, enxertadas em porta-enxerto Pyrus calleryana. O experimento foi realizado em blocos ao acaso, com seis tratamentos e quatro repetições. Os tratamentos consistiram na testemunha (sem aplicação de P-Ca e sem PR), em duas doses de P-Ca (300 e $600 \mathrm{mg} \mathrm{L}^{-1}$ ), em duas intensidades de poda de raiz (realizada em um ou nos dois lados da planta) e na poda de raiz em um lado da planta $+300 \mathrm{mg} \mathrm{L}^{-1}$ de P-Ca. A P-Ca reduziu o crescimento vegetativo mais efetivamente do que a PR, em ambas as safras, e a combinação de ambas as técnicas não resultou em controle adicional do crescimento vegetativo, em comparação à P-Ca utilizada sozinha. O crescimento vegetativo não foi influenciado pelo incremento nas doses de $\mathrm{P}$-Ca. A maior dose de $\mathrm{P}-\mathrm{Ca}$ afetou negativamente a produtividade de frutos. Quanto à qualidade de frutos, a PR aumenta o teor de sólidos solúveis totais na colheita.
\end{abstract}

Termos para indexação: Pyrus pyrifolia, qualidade de fruto, fitorreguladores, pomar adensado, vigor vegetativo, componentes da produção.

\section{Introduction}

Vegetative growth control of fruit trees is necessary to avoid excessive shading within the canopy, in order to promote interception of solar radiation and improve fruit quality (Rademacher, 2004). Excessive vegetative growth negatively affects yield (Pasa et al., 2011) and the control of pests and diseases - due to the reduced efficiency of sanitary applications (Miller \& Tworkoski, 2003) -, and increases pruning costs (Hawerroth et al., 2012). For achieving economically satisfactory production and improving fruit quality, management 
techniques that promote a proper balance between vegetative growth and fruiting must be used (Sharma et al., 2009), especially in vigorous cultivars and rootstocks.

The main techniques for controlling vegetative growth in fruit trees are branch bending, pruning, and the use of dwarfing rootstocks. Branch bending leads to reduced shoot growth by decreasing apical dominance. In Brazil, studies about dwarfing rootstocks are recent, and there are few options available for pears (Hawerroth et al., 2012). Control of vegetative growth by summer and winter pruning, therefore, is essential to ensure the productivity of orchards and to improve fruit quality (Cline et al., 2008). However, summer and winter pruning may increase production costs. In this context, the use of growth regulators and root pruning (RP) is an alternative to reduce excessive vegetative growth of pear trees [Pyrus pyrifolia (Burm) Nakai], in order to provide an adequate balance between vegetative growth and fruiting.

$\mathrm{P}-\mathrm{Ca}$ is a gibberellin (GA) biosynthesis inhibitor (Rademacher, 2004) used to control vegetative growth of different crops. Several studies have shown its efficiency in different pear cultivars (Sugar et al., 2004; Asín et al., 2007, Hawerroth et al., 2012; Einhorn et al., 2014; Pasa \& Einhorn, 2014). As to RP, it is a method used to reduce root area - reducing the flow of nutrients, water and hormones from the roots to the shoots -, limiting its growth. According to Rodriguez-Gamir et al. (2010), $\mathrm{RP}$ is an effective tool for controlling vegetative growth. Reduction in shoot number and shoot length of root pruned trees have been observed (Asín et al., 2007; Maas, 2008; Vercammen et al., 2005), as well as a higher number of flower buds and a more regular production (Vercammen et al., 2005). Maas (2008) observed that none or only small benefits can be derived from the use of plant growth regulators when RP is used to control vegetative growth, but this demands further verification for Brazilian orchards conditions.

The objective of this work was to evaluate the effect of prohexadione calcium and root pruning on the control of the vegetative growth and on fruit production and quality of 'Shinseiki' pear trees, under climatic conditions of Southern Brazil.

\section{Materials and Methods}

The experiment was carried out at the experimental field of the Universidade Federal de Pelotas, in the municipality of Capão do Leão, state of Rio Grande do Sul, Brazil ( $31^{\circ} 52^{\prime} 00^{\prime \prime} \mathrm{S}$, 52 $21^{\circ} 24^{\prime \prime} \mathrm{W}$, and 48-m altitude), during the 2013/2014 and 2014/2015 growing seasons. According to Köppen's classification, the climate of the studied region is $\mathrm{Cfa}$, i.e., humid subtropical, with annual rainfall average of $1,367 \mathrm{~mm}$, temperature of $17.8^{\circ} \mathrm{C}$, and humidity of $80.7 \%$. The average accumulation of chill hours below $7.2^{\circ} \mathrm{C}$ is 321 , during the winter, according to data provided by the Pelotas weather station. The soil in the experimental area is an Argissolo Amarelo distrófico (Ultisol), according to the Brazilian classification (Santos et al., 2013).

Plantmaterial consisted offifteen-year-old 'Shinseiki' pear trees ( $P$. pyrifolia), grafted onto $P$. calleryana rootstock. Trees were spaced $2 \times 5 \mathrm{~m}$, totaling 1,000 trees $\mathrm{ha}^{-1}$, and trained to a central-leader system. The trees were planted in a north-south row orientation, so that they could intercept the maximum amount of sunlight during the growing season. The experiment was arranged in a randomized complete block design, with six treatments - combinations of prohexadione calcium (P-Ca) doses and root pruning (RP) - and four replications of three trees each. Only the central tree was evaluated (experimental unit), while the other two were used as border. The trees were selected according to their uniformity and size (canopy volume), and then grouped into blocks based on trunk circumference measured $25 \mathrm{~cm}$ above the ground.

The trees were pruned at the end of the winter period in both seasons (August 12, 2013; and August 18, 2014), and, after 15 days, Erger (5\%, added to $5 \%$ calcium nitrate) was applied for induction and standardization of budburst and flowering. The treatments were applied to the same trees in both growing seasons, and they consisted of: control, without $\mathrm{P}-\mathrm{Ca}$ applicaiton and without RP; RP in one side of the tree (1S); RP in two sides of the tree (2S); P-Ca at $300 \mathrm{mg} \mathrm{L}^{-1}$ of active ingredient (a.i.); P-Ca $600 \mathrm{mg} \mathrm{L}^{-1}$ a.i.; and RP $1 \mathrm{~S}+\mathrm{P}-\mathrm{Ca} 300 \mathrm{mg} \mathrm{L}^{-1}$ of a.i. All P-Ca treatments were sprayed when shoots were $5-10 \mathrm{~cm}$ long. The $\mathrm{P}-\mathrm{Ca}$ source was the commercial product Viviful $(27.5 \%$ a.i.; Iharabras S.A., Chemical Industries). Solutions of P-Ca were supplemented with $0.05 \%$ (v:v) of surfactant Silwet L-77 Ag $\left(0.5 \mathrm{~mL} \mathrm{~L}^{-1}\right)$. RP was performed at the end of August, during the dormancy period, in both seasons, four to five weeks before the flowering start, which occurred on September 15, 2013, and October 
13, 2014. In the case of RP 1S, root pruning was performed in the east side. P-Ca was sprayed to the point of product runoff in the plant, using a motorized backpack sprayer Jacto. For RP, an agricultural tool with a blade coupled to a tractor was used. The blade was set to a cutting depth of $50 \mathrm{~cm}$, and it was passed $50 \mathrm{~cm}$ apart from the trunk.

Shoot length was measured with a metric tape on 10 one-year-old shoots, with similar diameters, in the four quadrants of the plant, at similar heights. The shoots were tagged at the time of the first P-Ca application and, then, at biweekly intervals until the end of the season. Similarly, fruit diameter in the 2013/2014 season was measured on 10 fruits with similar diameters, in the four quadrants of the tree, at a similar height. The fruits were evenly selected and tagged between 20 and 25 days after full bloom (DAFB) and, then, at biweekly intervals until harvest. Average growth rate $\left(\mathrm{mm} \mathrm{day}^{-1}\right)$ was calculated using biweekly shoot length data. Trunk diameter was measured at $25-\mathrm{cm}$ height from the soil surface with a digital caliper, at the beginning of the trial and at the end of each season, and expressed as trunk cross sectional area (TCSA, $\left.\mathrm{cm}^{2}\right)$, calculated according to Pasa et al. (2012). In order to calculate TCSA increase, the values obtained at the end of each season were subtracted from previous season TCSA.

The total number of flower clusters per tree was recorded at full bloom. After natural fruit drop (3040 DAFB), the remaining fruits in each tree were counted and fruit set was calculated according to the ratio (number of fruits per tree)/(number of flower clusters per tree), and expressed as the percentage of fruit per flower cluster. Full bloom occurred on October 09, 2013; October 28, 2014; and September 18, 2015. After fruit set evaluation, thinning was performed, which left two to three fruits per flower cluster. Yield components of 2014/2015 growing season were not recorded due to almost total abortion of flower buds, probably due to insufficient accumulation of chilling hours bellow $7.2^{\circ} \mathrm{C}$ (264 hours), in Pelotas, during the winter of 2014. In the previous winter (2013), the accumulation of chilling hours was 464 hours.

Trees were pruned in the summer and the winter. In both occasions, number and weight of pruned shoots were recorded and, in the winter pruning, their length was also measured. Summer pruning was done in the second half of December, in both seasons, approximately $60 \mathrm{DAFB}$, when all the upright shoots within the canopy were cut, which left a portion of the shoot with two buds $(\approx 10 \mathrm{~cm})$. Winter pruning was performed at the end of dormancy period, in both seasons, with the cutting of vigorous, upright, and poorly positioned shoots in the canopy.

Fruit were harvested at commercial timing on January 23, 2014 (106 DAFB), and fruit per tree were counted and weighted. Estimated yield was calculated based on the yield per tree and on the number of trees per ha. The average fruit weight was calculated by dividing the yield per tree by the number of fruits per tree. Fruit qualitative attributes were determined in a sample of 10 fruits per tree, randomly selected at harvest.

The qualitative attributes of the fruit analyzed were fruit firmness (FF), total soluble solids (TSS), and titratable acidity (TA). Fruit firmness was determined by removing fruit skin on two opposite sides of each fruit, using a digital penetrometer with an $8 \mathrm{~mm}$ diameter probe, and expressed in Newton (N). To measure the total soluble solids (TSS), the sample was juiced and placed in a digital refractometer model Atago PAL-1, and expressed as ${ }^{\circ}$ Brix. Titratable acidity (TA) was calculated according to Carra et al. (2016), and expressed as the percentage of malic acid.

Statistical analysis was performed using the $\mathrm{R}$ software (R Core Team, 2014), with the package ExpDes (Ferreira et al., 2013). Data expressed as percentage or counts were transformed when they did not meet the assumptions for analysis of variance, using the $\arcsin$ [square root $(n+1)$ ] and square root $(n+0.5)$ transformations, respectively. When the F test was significant, treatment means were compared with Duncan's test, at 5\% probability.

\section{Results and Discussion}

The treatments significantly reduced shoot growth and TCSA increment compared to control, in both seasons (Figure 1 and Table 1). Shoots of RP trees (1S and $2 \mathrm{~S}$ ) showed lower reduction in length compared to trees treated with $\mathrm{P}-\mathrm{Ca}$ - regardless of the application rate - and to RP 1S + P-Ca $300 \mathrm{mg} \mathrm{L}^{-1}$, in the 2013/2014 growing season. Similar results were also observed in the 2014/2015 growing season, but RP 1S did not differ from P-Ca $300 \mathrm{mg} \mathrm{L}^{-1}$. The differences in shoot growth rate observed from 36 DAFB in 2013/2014, and from 28 DAFB in 2014/2015 are shown in Figure 1. 
The vegetative growth control provided by $\mathrm{P}-\mathrm{Ca}$ and $\mathrm{RP}$, and by their association, was effective during the
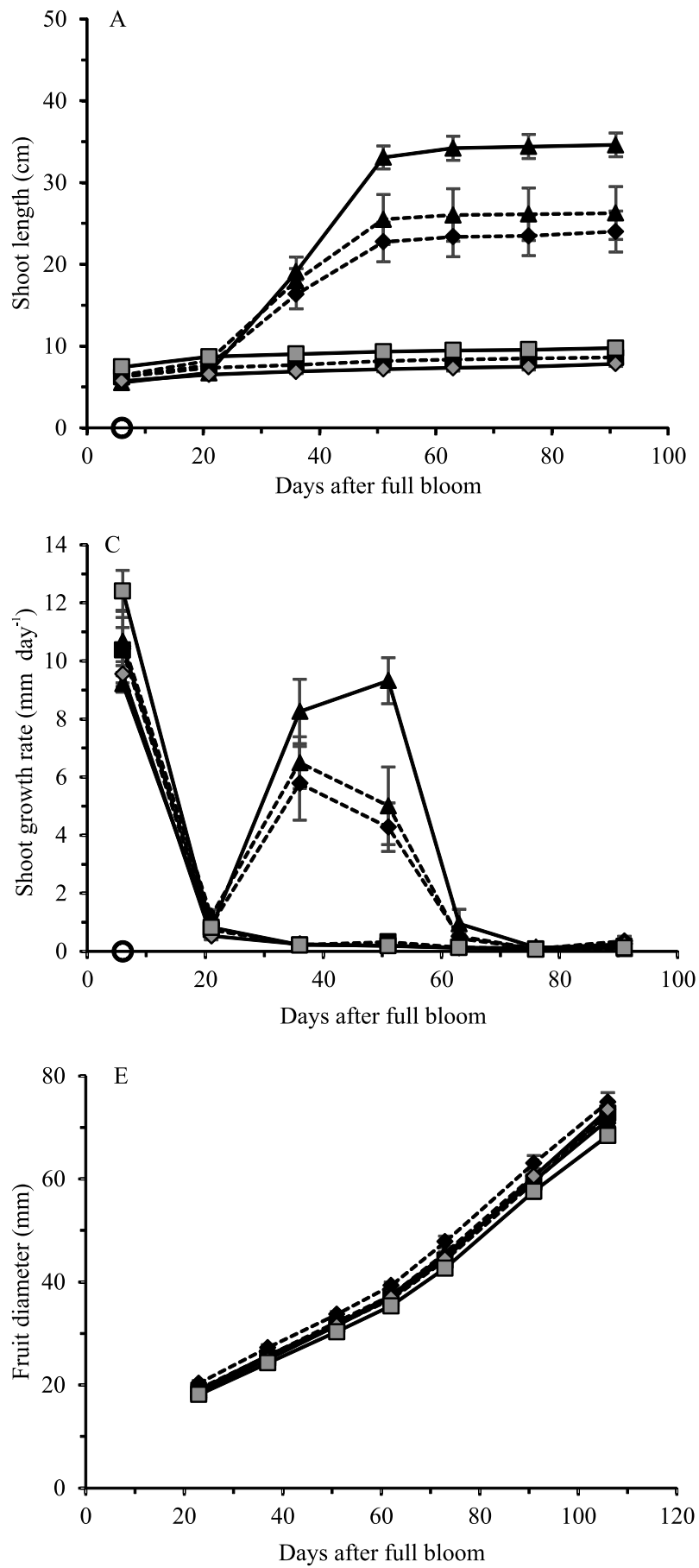

whole season, and $\mathrm{P}-\mathrm{Ca}$ induced greater reduction in shoot growth than RP (Figure 1).
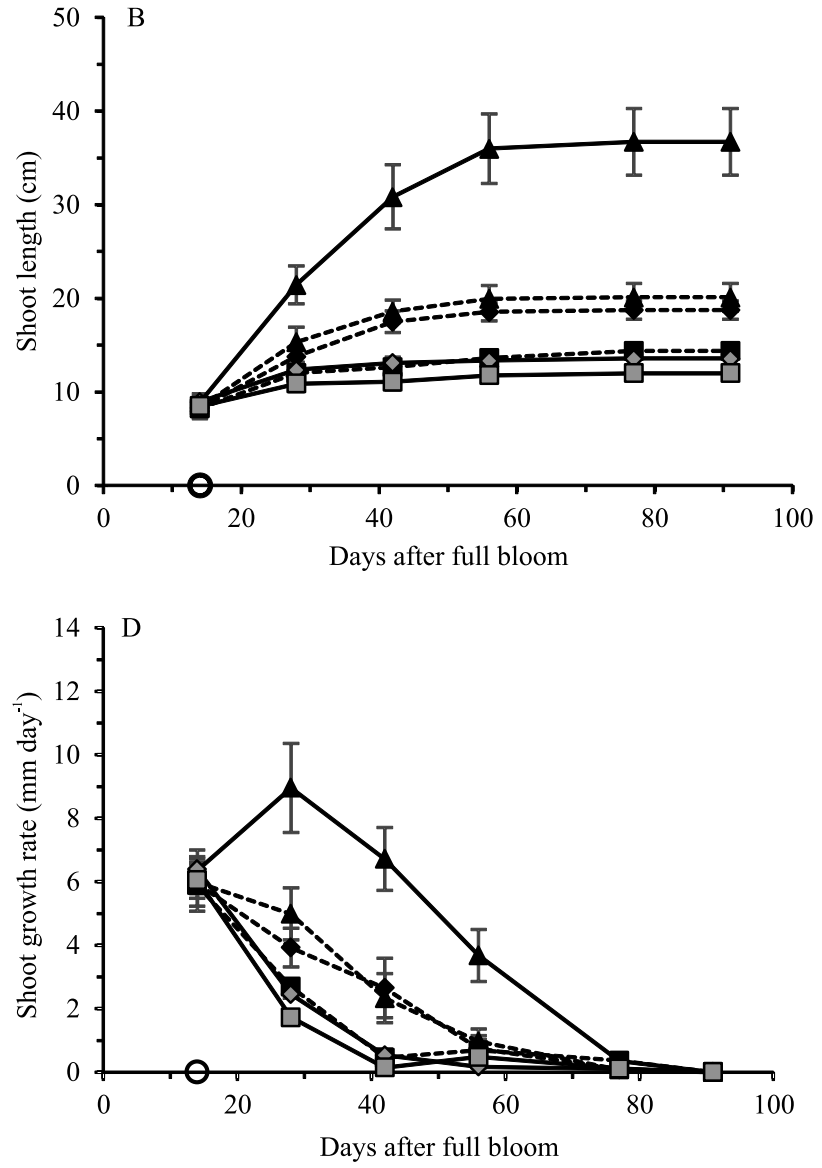

Figure 1. Shoot length (A and B), shoot growth rate (C and D), and fruit diameter (E) of 'Shinseiki' pear trees treated with prohexadione calcium (P-Ca) and root pruning (RP), in the 2013/2014 (A, C and E) and the 2014/2015 (B and D) growing seasons. Circle on the $\mathrm{x}$-axis denotes the application of P-Ca. Vertical bars represent \pm standard error. 
The results with $\mathrm{P}-\mathrm{Ca}$ application show the effectiveness of this plant regulator to control vegetative growth of 'Shinseiki' pears. Several authors reported vegetative growth reduction in pear trees by using P-Ca (Costa et al., 2004; Rademacher, 2004; Smit et al., 2005; Hawerroth et al., 2012; Einhorn et al., 2014; Pasa \& Einhorn, 2014; Carra et al., 2016). Moreover, the association of RP with P-Ca application did not result in additional vegetative growth control, when compared to P-Ca used alone (Table 1). Similar results were observed by Maas (2008), who also found no synergistic effect of the combination of RP and P-Ca.

In 'Housui' pear trees sprayed with different rates of P-Ca, Hawerroth et al. (2012) reported 31-50\% reduction in shoot length, at 146 DAFB, compared to control trees. Additionally, Einhorn et al. (2014) observed reduction of up to $70 \%$ in the shoot growth of 'd'Anjou' pear trees treated once with $250 \mathrm{mg} \mathrm{L}^{-1} \mathrm{P}-\mathrm{Ca}$.

As to RP, Asín et al. (2007) reported that 'Blanquilla' pear trees, root pruned in both sides of the plants $(40 \mathrm{~cm}$ from the stem, at $40-\mathrm{cm}$ depth), showed a reduction of $25 \%$ in final shoot lengths. Vercammen et al. (2005) observed that 'Conference' pear trees treated with RP $1 \mathrm{~S}$, performed for two consecutive years, and RP 2S, in a single year, had their vegetative growth reduced in $27 \%$ and $44 \%$, respectively. In a two-year study developed by Wang et al. (2014b), pear trees treated with RP $2 \mathrm{~S}$ (40 $\mathrm{cm}$ from the stem, at $30-\mathrm{cm}$ depth) showed reduction of $72 \%$ in total shoot length.

Table 1. Total shoot length and trunk cross-sectional area (TCSA) increases of 'Shinseiki' pear trees as affected by prohexadione calcium (P-Ca) application and root pruning (RP) in the 2013/2014 and 2014/2015 growing seasons ${ }^{(1)}$.

\begin{tabular}{lccccc}
\hline Treatment & \multicolumn{2}{c}{$2013 / 2014$} & & \multicolumn{2}{c}{$2014 / 2015$} \\
\cline { 2 - 3 } \cline { 6 - 7 } & $\begin{array}{c}\text { Shoot } \\
\text { length } \\
(\mathrm{cm})\end{array}$ & $\begin{array}{c}\text { TCSA } \\
\text { increase } \\
\left(\mathrm{cm}^{-2}\right)\end{array}$ & & $\begin{array}{c}\text { Shoot } \\
\text { length } \\
(\mathrm{cm})\end{array}$ & $\begin{array}{c}\text { TCSA } \\
\text { increase } \\
\left(\mathrm{cm}^{-2}\right)\end{array}$ \\
\hline Control & $34.60 \mathrm{a}$ & $16.08 \mathrm{a}$ & & $36.72 \mathrm{a}$ & $22.43 \mathrm{a}$ \\
RP 1S & $24.00 \mathrm{~b}$ & $11.80 \mathrm{~b}$ & & $18.74 \mathrm{bc}$ & $15.30 \mathrm{~b}$ \\
RP 2S & $26.27 \mathrm{~b}$ & $10.50 \mathrm{c}$ & & $20.12 \mathrm{~b}$ & $16.35 \mathrm{~b}$ \\
P-Ca 300 mg L-1 & $8.60 \mathrm{c}$ & $9.91 \mathrm{~cd}$ & & $14.37 \mathrm{~cd}$ & $14.37 \mathrm{~b}$ \\
P-Ca 600 mg L-1 & $7.84 \mathrm{c}$ & $9.15 \mathrm{~d}$ & & $13.58 \mathrm{~d}$ & $14.11 \mathrm{~b}$ \\
RP 1S + P-Ca 300 mg L & $9.74 \mathrm{c}$ & $9.52 \mathrm{~d}$ & & $12.00 \mathrm{~d}$ & $14.55 \mathrm{~b}$ \\
\hline CV (\%) & 23.16 & 5.14 & & 16.77 & 11.04 \\
$\mathrm{p}$ & 0.01 & 0.01 & & 0.01 & 0.01 \\
\hline
\end{tabular}

(1)Means followed by equal letters do not differ by Duncan's test at $5 \%$ probability. RP 1S, root pruning performed in one side of the pear tree; and RP $2 \mathrm{~S}$, root pruning performed in both sides of the tree.
The reduction of vegetative growth in root pruned pear trees may be related to a lower absorption of water (Janssens et al., 2011) and nutrients (Wang et al., 2014a) by the tree, due to the reduced volume of soil occupied by roots. Moreover, the roots are the main site of cytokinin synthesis, a plant hormone responsible for cell division and elongation (Fosket \& Kieber, 2013) that plays an important role on the promotion of vegetative growth. Therefore, the reduction in root volume would reduce the levels of cytokinin transported to the canopy, thus limiting its growth.

In both seasons, the treatments resulted in lower increase of TCSA compared to control (Table 1). The lowest values were observed with P-Ca $300 \mathrm{mg} \mathrm{L}^{-1}$ and $600 \mathrm{mg} \mathrm{L}^{-1}$, and with RP 1S + P-Ca $300 \mathrm{mg} \mathrm{L}^{-1}$. Reduction in TCSA increases in response to $\mathrm{P}-\mathrm{Ca}$ application was also found in apple trees (Zadravec et al., 2008). In the first season, RP $1 S$ and RP $2 S$ resulted in a reduction of 26.62 to $34.7 \%$ in TCSA increases, compared to control. Significant differences were observed between these two levels of root pruning; with RP $2 \mathrm{~S}$ showing reduction in TCSA increase similar to that observed with the application of P-Ca $300 \mathrm{mg} \mathrm{L}^{-1}$. Ferree \& Knee (1997) reported similar results for apple trees, where in the first 5 years of RP, 'Golden Delicious' apple trees showed a reduction of $14 \%$ in TCSA increase, and, in the sixth year, a $22 \%$ reduction. In the second season, the reduction in TCSA increases for all treatments ranged from 27 to $37 \%$, compared to control.

Regarding summer pruning, trees treated with RP and P-Ca showed smaller number and lower weight of pruned shoots, compared to control, in both seasons, except for RP 1S in the 2014/2015 season (Table 2). This decrease was most evident in trees treated with $\mathrm{P}-\mathrm{Ca}$, either alone or combined with RP, where a reduction of $\sim 65 \%$ in the number of pruned shoots per tree, and of $\sim 74 \%$ in pruning weight was observed in both seasons. The reduction in the number and weight of pruned shoots of RP treated trees was intermediate, but significantly different from control, except for RP $1 \mathrm{~S}$ in the second season.

Significant results were also observed in winter pruning for the number, weight, and length of pruned shoots per tree, (Table 2). In the first season, the number of pruned shoots was lower with $\mathrm{P}-\mathrm{Ca}$ and RP 1S + P-Ca $300 \mathrm{mg} \mathrm{L}^{-1}$. In the second season, the lowest values were observed with $\mathrm{P}-\mathrm{Ca}$ application, 
RP 1S + P-Ca $300 \mathrm{mg} \mathrm{L}^{-1}$, and RP 2S, followed by RP 1S. The lowest weight of pruned shoots was observed with RP 1S + P-Ca $300 \mathrm{mg} \mathrm{L}^{-1}$, followed by treatments with both rates of $\mathrm{P}-\mathrm{Ca}$, and by RP $1 \mathrm{~S}$ and $2 \mathrm{~S}$, in the 2013/2014 season. In the second season, RP 1S + P-Ca $300 \mathrm{mg} \mathrm{L}^{-1}$ and P-Ca $600 \mathrm{mg} \mathrm{L}^{-1}$ showed lower pruning weight than RP $1 \mathrm{~S}$ and control. That was the single

Table 2. Effects of prohexadione calcium (P-Ca) application and root pruning (RP) on the number (NPS) and mass (MPS) of pruned shoots per tree in summer and winter prunings, and total length of pruned shoots per tree (LPS) in winter pruning of 'Shinseiki' pear trees ${ }^{(1)}$.

\begin{tabular}{|c|c|c|c|c|c|}
\hline \multirow[t]{2}{*}{ Treatment } & \multicolumn{2}{|c|}{ Summer pruning } & \multicolumn{3}{|c|}{ Winter pruning } \\
\hline & NPS & MPS (g) & NPS & MPS $(g)$ & $\overline{L P S}(\mathrm{~cm})$ \\
\hline & \multicolumn{5}{|c|}{ 2013/2014 growing season } \\
\hline Control & $68.3 \mathrm{a}$ & $1,747.5 \mathrm{a}$ & $30.0 \mathrm{a}$ & $599.0 \mathrm{a}$ & $1,220.8 \mathrm{a}$ \\
\hline RP 1S & $47.0 \mathrm{~b}$ & $1,117.0 \mathrm{~b}$ & $24.0 \mathrm{a}$ & $416.5 b$ & $720.3 b$ \\
\hline $\mathrm{RP} 2 \mathrm{~S}$ & $41.5 b$ & $960.0 \mathrm{~b}$ & $22.8 \mathrm{a}$ & $424.5 b$ & $818.3 b$ \\
\hline P-Ca $300 \mathrm{mg} \mathrm{L}^{-1}$ & $24.5 \mathrm{c}$ & $494.8 \mathrm{c}$ & $15.0 \mathrm{~b}$ & $328.0 \mathrm{c}$ & $602.8 b c$ \\
\hline P-Ca $600 \mathrm{mg} \mathrm{L}^{-1}$ & $21.3 \mathrm{c}$ & $434.0 \mathrm{c}$ & $9.8 \mathrm{~b}$ & $317.0 \mathrm{c}$ & $472.8 \mathrm{c}$ \\
\hline $\mathrm{RP} 1 \mathrm{~S}+\mathrm{P}-\mathrm{Ca} 300 \mathrm{mg} \mathrm{L}^{-1}$ & $20.3 \mathrm{c}$ & $417.0 \mathrm{c}$ & $11.0 \mathrm{~b}$ & $245.5 \mathrm{~d}$ & $409.8 \mathrm{c}$ \\
\hline$\overline{\mathrm{CV}}(\%)$ & 6.36 & 12.34 & 12.79 & 10.2 & 19.76 \\
\hline \multirow[t]{2}{*}{$\mathrm{p}$} & 0.01 & 0.01 & 0.01 & 0.01 & 0.01 \\
\hline & \multicolumn{5}{|c|}{ 2014/2015 growing season } \\
\hline Control & $71.3 \mathrm{a}$ & $1,934.5 \mathrm{a}$ & $32.5 \mathrm{a}$ & $657.1 \mathrm{a}$ & $1,082.9 \mathrm{a}$ \\
\hline RP 1S & $59.3 \mathrm{ab}$ & $1,362.5 b$ & $23.0 \mathrm{~b}$ & $339.3 b$ & $621.0 \mathrm{~b}$ \\
\hline $\mathrm{RP} 2 \mathrm{~S}$ & $45.5 b$ & $1,006.0 \mathrm{~b}$ & $17.5 \mathrm{c}$ & $313.8 \mathrm{bc}$ & $494.5 \mathrm{bc}$ \\
\hline P-Ca $300 \mathrm{mg} \mathrm{L}^{-1}$ & $26.0 \mathrm{c}$ & $476.5 \mathrm{c}$ & $15.3 \mathrm{c}$ & $223.8 \mathrm{bc}$ & $373.7 \mathrm{bc}$ \\
\hline P-Ca $600 \mathrm{mg} \mathrm{L}^{-1}$ & $25.8 \mathrm{c}$ & $496.5 \mathrm{c}$ & $13.8 \mathrm{c}$ & $194.5 \mathrm{c}$ & $351.8 \mathrm{bc}$ \\
\hline$\underline{\mathrm{RP}} 1 \mathrm{~S}+\mathrm{P}-\mathrm{Ca} 300 \mathrm{mg} \mathrm{L}^{-1}$ & $18.3 \mathrm{c}$ & $379.8 \mathrm{c}$ & $14.3 \mathrm{c}$ & $189.3 \mathrm{c}$ & $297.9 \mathrm{c}$ \\
\hline$\overline{\mathrm{CV}(\%)}$ & 12.53 & 27.02 & 7.97 & 26.07 & 24.67 \\
\hline $\mathrm{p}$ & 0.01 & 0.01 & 0.01 & 0.01 & 0.01 \\
\hline
\end{tabular}

(1) Means followed by equal letters do not differ by Duncan's test at $5 \%$ probability. RP 1S, root pruning performed in one side of the pear tree; and RP 2S, root pruning performed in both sides of the tree. variable where RP $1 \mathrm{~S}+\mathrm{P}-\mathrm{Ca} 300 \mathrm{mg} \mathrm{L}^{-1}$ showed a significant difference compared to treatments with P-Ca applications alone, in 2013/2014 season, proving the effects of the combination of both techniques to be minimal in controlling vegetative growth of pear trees, as observed by Maas (2008). For total shoot length of pruned shoots, the major reduction was observed with $\mathrm{RP} 1 \mathrm{~S}+\mathrm{P}-\mathrm{Ca} 300 \mathrm{mg} \mathrm{L}^{-1}$ and P-Ca $600 \mathrm{mg} \mathrm{L}^{-1}$.

Similar results were observed for 'Housui' pear trees treated with $\mathrm{P}-\mathrm{Ca}$, where the reduction in pruning weight per tree (winter pruning) ranged from 28.6 to $63 \%$ compared to control trees, while the reduction of the number of pruned shoots ranged from 39.3 to $66.7 \%$ (Hawerroth et al., 2012). According to Wang et al. (2014b), root pruned pear trees showed a decrease of $43 \%$ in the number of shoots per tree. The decrease in number, weight and total length of shoots pruned in 'Shinseiki' pear trees, in response to RP and P-Ca application, indicates that these two vegetative growth control methods minimize the formation of strong vegetative drains. They also reduce the excessive growth and the need for summer and winter pruning, which is an important component of the cost for pear orchards, representing approximately $14 \%$ of total variable cost (Seavert et al., 2005).

$\mathrm{RP}$ and P-Ca applications did not affect fruit set and the number of fruits before and after thinning, compared to control trees in the 2013/2014 season (Table 3). Similar results were reported for P-Ca applications (Sugar et al., 2004) and RP (Asín et al., 2007), where fruit set and the number of fruits per tree were not significantly affected. Einhorn et al. (2014), however, observed contrasting results, where the

Table 3. Effect of prohexadione calcium (P-Ca) and root pruning (RP) on fruit set, number of fruits before thinning (BT), number of fruits after thinning (AT), fruit yield, average fruit weight, and estimated yield of 'Shinseiki' pear trees, in the 2013/2014 growing season ${ }^{(1)}$.

\begin{tabular}{|c|c|c|c|c|c|c|}
\hline \multirow[t]{2}{*}{ Treatment } & \multirow{2}{*}{ Fruit set $(\%)$} & \multicolumn{2}{|c|}{ Number of fruits per tree } & \multirow{2}{*}{$\begin{array}{c}\text { Yield } \\
\left(\mathrm{kg} \text { tree }{ }^{-1}\right)\end{array}$} & \multirow{2}{*}{$\begin{array}{c}\text { Average fruit } \\
\text { weight }(\mathrm{g})\end{array}$} & \multirow{2}{*}{$\begin{array}{c}\text { Estimated yield } \\
\left(\mathrm{Mg} \mathrm{ha}^{-1}\right)\end{array}$} \\
\hline & & Before thinning & After thinning & & & \\
\hline Control & 95.28 & 317.8 & 220.5 & $38.14 a$ & $172.93 a$ & $38.14 a$ \\
\hline RP 1S & 91.89 & 255.3 & 178.3 & $32.54 \mathrm{ab}$ & $171.42 \mathrm{a}$ & $32.54 \mathrm{ab}$ \\
\hline $\mathrm{RP} 2 \mathrm{~S}$ & 90.54 & 328.8 & 206.0 & $37.97 \mathrm{a}$ & $178.79 \mathrm{a}$ & $37.97 \mathrm{a}$ \\
\hline P-Ca $300 \mathrm{mg} \mathrm{L}^{-1}$ & 89.49 & 287.3 & 211.3 & $38.47 \mathrm{a}$ & $169.67 \mathrm{a}$ & $38.47 \mathrm{a}$ \\
\hline P-Ca $600 \mathrm{mg} \mathrm{L}^{-1}$ & 91.91 & 216.0 & 137.0 & $25.69 b$ & $168.51 \mathrm{a}$ & $25.69 b$ \\
\hline $\mathrm{RP} 1 \mathrm{~S}+\mathrm{P}-\mathrm{Ca} 300 \mathrm{mg} \mathrm{L}^{-1}$ & 93.96 & 303.3 & 184.0 & $29.94 \mathrm{ab}$ & $152.83 \mathrm{~b}$ & $29.94 \mathrm{ab}$ \\
\hline CV (\%) & 15.18 & 12.45 & 12.55 & 15.99 & 5.15 & 15.99 \\
\hline $\mathrm{p}$ & 0.92 & 0.26 & 0.18 & 0.01 & 0.01 & 0.01 \\
\hline
\end{tabular}

${ }^{(1)}$ Means followed by equal letters do not differ by Duncan's test at 5\% probability. RP 1S, root pruning performed in one side of the pear tree; and RP $2 \mathrm{~S}$, root pruning performed in both sides of the tree. 
application of P-Ca $250 \mathrm{mg} \mathrm{L}^{-1}$ increased fruit set of 'd'Anjou' pears.

Fruit diameter during the season and final fruit diameter were not affected by RP or by $\mathrm{P}-\mathrm{Ca}$ applications, compared to control trees (Figure 1). Nonetheless, the average fruit weight was significantly reduced by RP 1S + P-Ca $300 \mathrm{mg} \mathrm{L}^{-1}$ in the 2013/2014 season (Table 3). These results do not corroborate those by Hawerroth et al. (2012), which observed a linear increase of fruit diameter of 'Housui' pear trees treated with P-Ca. In this study, pear trees treated with RP 1S + P-Ca $300 \mathrm{mg} \mathrm{L}^{-1}$ had lower average fruit weight compared to the other treatments, showing that the association of both techniques may negatively affect fruit size. Smaller average fruit weight was also observed in other studies with pears treated with RP (Wang et al., 2014b) or P-Ca (Smit et al., 2005). Additionally, Maas (2008) observed that average fruit weight of 'Conference' pears was not affected by RP and $\mathrm{RP}+\mathrm{P}-\mathrm{Ca}$.

Yield was negatively affected by P-Ca $600 \mathrm{mg} \mathrm{L}^{-1}$ in the 2013/2014 season, even though it did not significantly differ from RP $1 \mathrm{~S}$ and $\mathrm{RP} 1 \mathrm{~S}+\mathrm{P}-\mathrm{Ca}$ $300 \mathrm{mg} \mathrm{L}^{-1}$ (Table 3). Similar results were found by Hawerroth et al. (2012), where 'Housui' pear trees sprayed with P-Ca rates greater than $584 \mathrm{mg} \mathrm{L}^{-1}$ showed reduced yield. However, contrary results were found by Asín et al. (2007), who observed that 'Blanquilla' pears sprayed with $\mathrm{P}-\mathrm{Ca} 1,750 \mathrm{mg} \mathrm{L}^{-1}$, split in four monthly applications, and 'd'Anjou' pears sprayed once with P-Ca $250 \mathrm{mg} \mathrm{L}^{-1}$ (Einhorn et al., 2014) did not significantly reduce its yield per tree.

RP performed alone did not affect yield in the present study; and Asín et al. (2007) reported that root pruned 'Blanquilla' trees showed increased yield compared to control trees. Wang et al. (2014b), however, reported reduced yield of 'Clara Frijs' pear trees treated with RP, in the first year, but increased yield in the next season, compared to control trees.

TSS in harvested fruits was significantly affected by the treatments (Table 4). The highest content of TSS was observed with RP $1 \mathrm{~S}$ and $2 \mathrm{~S}$, which, however, did not significantly differ, from P-Ca $600 \mathrm{mg} \mathrm{L}^{-1}$. Vercammen et al. (2005) also observed higher content of TSS in fruits of root pruned pear trees. These results may be explained by the decreased translocation of water to the fruit at ripening stage, increasing the TSS concentration. Pasa et al. (2012) observed that the least
Table 4. Effect of prohexadione calcium (P-Ca) and root pruning (RP) treatments on fruit firmness, total soluble solids and titratable acidity (TA) of 'Shinseiki' pears in the 2013/2014 growing season ${ }^{(1)}$.

\begin{tabular}{lccc}
\hline Treatment & $\begin{array}{c}\text { Fruit firmness } \\
(\mathrm{N})\end{array}$ & $\begin{array}{c}\text { Total soluble } \\
\left.\text { solids ( }{ }^{\circ} \text { Brix }\right)\end{array}$ & $\begin{array}{c}\text { TA (\% of } \\
\text { malic acid) }\end{array}$ \\
\hline Control & 43.57 & $10.10 \mathrm{~b}$ & 0.110 \\
RP 1S & 41.70 & $11.23 \mathrm{a}$ & 0.124 \\
RP 2S & 41.71 & $11.03 \mathrm{a}$ & 0.110 \\
P-Ca 300 mg L-1 & 43.26 & $10.13 \mathrm{~b}$ & 0.106 \\
P-Ca 600 mg L-1 & 43.23 & $10.70 \mathrm{ab}$ & 0.101 \\
RP 1S + P-Ca 300 mg L & & $10.08 \mathrm{~b}$ & 0.096 \\
\hline CV (\%) & 42.02 & 4.57 & 13.610 \\
p & 2.97 & 0.01 & 0.189 \\
\hline
\end{tabular}

(1) Means followed by equal letters do not differ by Duncan's test at $5 \%$ probability. RP 1S, root pruning performed in one side of the pear tree; and RP $2 \mathrm{~S}$, root pruning performed in both sides of the tree.

vigorous rootstocks induced the formation of fruits with highest TSS contents.

Fruit firmness (FF) at harvest was not affected by treatments, similarly as the reports by Smit et al. (2005) and Einhorn et al. (2014), which showed no effect of $\mathrm{P}-\mathrm{Ca}$ application on FF. Neither P-Ca application nor $\mathrm{RP}$ affected titratable acidity of fruit, which was also observed by Hawerroth et al. (2012), in 'Hosui' pear trees treated with P-Ca.

\section{Conclusions}

1. Root pruning (RP) and prohexadione calcium (P$\mathrm{Ca}$ ), when applied individually, consistently control vegetative growth of 'Shinseiki' pear trees cultivated in Southern Region of Brazil, but prohexadione calcium is more efficient.

2. The combination of $\mathrm{P}-\mathrm{Ca}$ and $\mathrm{RP}$ does not further improve vegetative growth control of pear trees.

3. Given the similar effects of the tested P-Ca rates in reducing vegetative growth, and the negative of the highest dose on fruit yield, the lowest one is recommended to control vegetative growth of 'Shinseiki' pear trees.

4. Root pruning increases the total soluble solids content at harvest.

\section{Acknowledgments}

To Coordenação de Aperfeiçoamento de Pessoal de Nível Superior (Capes) and to Conselho Nacional de 
Desenvolvimento Científico e Tecnológico (CNPq), for the grants.

\section{References}

ASÍN, L.; ALEGRE, S.; MONTSERRAT, R. Effect of paclobutrazol, prohexadione-Ca, deficit irrigation, summer pruning and root pruning on shoot growth, yield, and return bloom, in a 'Blanquilla' pear orchard. Scientia Horticulturae, v.113, p.142-148, 2007. DOI: 10.1016/j.scienta.2007.02.008.

CARRA, B.; PASA, M.S.; FACHINELLO, J.C.; SPAGNOL, D.; ABREU, E.S.; GIOVANAZ, M.A. Prohexadione calcium affects shoot growth, but not yield components, of 'Le Conte' pear in warm-winter climate conditions. Scientia Horticulturae, v.209, p.241-248, 2016. DOI: 10.1016/j.scienta.2016.06.036.

CLINE, J.A.; EMBREE, C.G.; HEBB, J.; NICHOLS, D.S. Performance of prohexadione-calcium on shoot growth and fruit quality of apple - effect of spray surfactants. Canadian Journal of Plant Science, v.88, p.165-174, 2008. DOI: 10.4141/CJPS07087.

COSTA, G.; SABATINI, E.; SPINELLI, F.; ANDREOTTI, C.; SPADA, G.; MAZZINI, F. Prohexadione-Ca controls vegetative growth and cropping performance in pear. Acta Horticulturae, v.653, p.127-132, 2004. DOI: 10.17660/ActaHortic.2004.653.16.

EINHORN, T.C.; PASA, M.S., TURNER, J. 'D'Anjou' pear shoot growth and return bloom, but not fruit size, are reduced by prohexadione-calcium. HortScience, v.49, p.180-187, 2014.

FERREE, D.C.; KNEE, M. Influence of root pruning and rootstock on growth and performance of 'Golden Delicious' apple. HortScience, v.32, p.645-648, 1997.

FERREIRA, E.B.; CAVALCANTI, P.P.; NOGUEIRA, D.A. ExpDes: Experimental Designs pacakge. 2013. R package version 1.1.2. Available at: <http://CRAN.R-project.org/ package $=$ ExpDes $>$. Accessed on: Jan. 132017.

FOSKET, D.E.; KIEBER, J. Citocininas: reguladores da divisão celular. In: TAIZ, L.; ZEIGER, E. Fisiologia vegetal. 5.ed. Porto Alegre: Artmed, 2013. p.619-646.

HAWERROTH, F.J.; PETRI, J.L.; FACHINELLO, J.C.; HERTER, F.G.; PREZORRO, M.E.; HASS, L.B.; PRETTO, A. Redução da poda hibernal e aumento da produção de pereiras 'Hosui' pelo uso de prohexadiona cálcio. Pesquisa Agropecuária Brasileira, v.47, p.939-947, 2012. DOI: 10.1590/S0100-204X2012000700010.

JANSSENS, P.; DECKERS, T.; ELSEN, F.; ELSEN, A.; SCHOOFS, H.; VERJANS, W.; VANDENDRIESSCHE, $H$. Sensitivity of root pruned 'Conference' pear to water deficit in a temperate climate. Agricultural Water Management, v.99, p.5866, 2011. DOI: 10.1016/j.agwat.2011.07.018.

MAAS, F. Strategies to control tree vigour and optimize fruit production in 'Conference' pears. Acta Horticulturae, v.800, p.139-146, 2008. DOI: 10.17660/ActaHortic.2008.800.12.

MILLER, S.S.; TWORKOSKI, T. Regulating vegetative growth in deciduous fruit trees. Plant Growth Regulation Society of America, v.31, p.8-46, 2003.
PASA, M. da S.; FACHINELLO, J.C.; SCHMITZ, J.D.; SOUZA, A.L.K. de; FRANCESCHI, E. de. Desenvolvimento, produtividade e qualidade de peras sobre porta-enxertos de marmeleiro e Pyrus calleryana. Revista Brasileira de Fruticultura, v.34, p.873-880, 2012. DOI: $10.1590 /$ S0100-29452012000300029.

PASA, M. da S.; FACHINELLO, J.C.; SCHMITZ, J.D.; SOUZA, A.L.K. de; HERTER, F.G. Hábito de frutificação e produção de pereiras sobre diferentes porta-enxertos. Pesquisa Agropecuária Brasileira, v.46, p.998-1005, 2011. DOI: 10.1590/S0100204X2011000900005.

PASA, M.S.; EINHORN, T.C. Heading cuts and prohexadionecalcium affect the growth and development of 'd'Anjou' pear shoots in a high-density orchard. Scientia Horticulturae, v.168, p.267-271, 2014. DOI: 10.1016/j.scienta.2014.02.003.

R CORE TEAM. R: a language and environment for statistical computing. Vienna: R Foundation for Statistical Computing, 2014. Available at: <http://www.R-project.org/>. Accessed on: Jan. 132017.

RADEMACHER, W. Chemical regulation of shoot growth in fruit trees. Acta Horticultura, v.653, p.29-32, 2004. DOI: 10.17660/ ActaHortic.2004.653.2.

RODRÍGUEZ-GAMIR, J.; INTRIGLIOLO, D.S.; PRIMMOMILLO, E.; FORNER-GINER, M.A. Relationships between xylem anatomy, root hydraulic conductivity, leaf/root ratio and transpiration in citrus trees on different rootstocks. Physiologia Plantarum, v.139, p.159-169, 2010. DOI: 10.1111/j.13993054.2010.01351.x.

SANTOS, H.G. dos; JACOMINE, P.K.T.; ANJOS, L.H.C. dos; OLIVEIRA, V.A. de; LUMBRERAS, J.F.; COELHO, M.R.; ALMEIDA, J.A. de; CUNHA, T.J.F.; OLIVEIRA, J.B. de. Sistema brasileiro de classificação de solos. 3.ed. rev. e ampl. Brasília: Embrapa, 2013. 353p.

SEAVERT, C.F.; MOORE, J.; CASTAGNOLI, S. The economic costs and returns of producing pears in Hood River, Oregon, USA. Acta Horticulturae, v.671, p.421-427, 2005. DOI: 10.17660/ ActaHortic.2005.671.59.

SHARMA, S.; REHALIA, A.S.; SHARMA, S.D. Vegetative growth restriction in pome and stone fruits - a review. Agricultural Reviews, v.30, p.13-23, 2009.

SMIT, M.; MEINTJES, J.J.; JACOBS, G.; STASSEN, P.J.C.; THERON, K.I. Shoot growth control of pear trees (Pyrus communis L.) with prohexadione-calcium. Scientia Horticulturae, v.106, p.515-529, 2005. DOI: 10.1016/j.scienta.2005.05.003.

SUGAR, D.; ELFVING, D.C.; MIELKE, E.A. Effects of prohexadione-calcium on fruit size and return bloom in pear. HortScience, v.39, p.1305-1308, 2004.

VERCAMMEN, J.; DAELE, G. van; GOMAND, A. Root pruning: a valuable alternative to reduce the growth of 'Conference'. Acta Horticulturae, v.671, p.533-537, 2005. DOI: 10.17660/ ActaHortic.2005.671.74.

WANG, Y.; BERTELSEN, M.G.; PETERSEN, K.K.; ANDERSEN, M.N.; LIU, F. Effect of root pruning and irrigation regimes on leaf water relations and xylem ABA and ionic concentrations in pear trees. Agricultural Water Management, v.135, p.84-89, 2014a. DOI: 10.1016/j.agwat.2013.12.017. 
WANG, Y.; TRAVERS, S.; BERTELSEN, M.G.; THORUPKRISTENSEN, K.; PETERSEN, K.K.; LIU, F. Effect of root pruning and irrigation regimes on pear tree: growth, yield and yield components. Horticultural Science, v.41, p.34-43, 2014b.
ZADRAVEC, P.; CMELIK, Z.; TOJNKO, S.; UNUK, T.; SCHLAUER, B. Vegetative growth, yield and fruit quality of 'Gala' apple treated with Regalis (Prohexadione-Ca). Acta Horticulturae, v.774, p.287-290, 2008. DOI: 10.17660/ ActaHortic.2008.774.38.

Received on June 7, 2016 and accepted on January 13, 2017 